\title{
Welcome message from the organizers
}

\author{
René Schumann ${ }^{1 *}$, Roman Rudel ${ }^{2}$ and Khoa Nguyen ${ }^{1}$ \\ From The 9th DACH+ Conference on Energy Informatics \\ Sierre, Switzerland. 29-30 October 2020
}

\author{
*Correspondence: \\ rene.schumann@hevs.ch \\ ${ }^{1}$ HES-SO Valais Wallis, SILab, Rue de \\ Technpole 3, 3960 Sierre, \\ Switzerland \\ Full list of author information is \\ available at the end of the article
}

Dear readers,

The recent environmental and societal developments, in particular, the climate change happening more and more visible to larger parts of the society and also the COVID-19 pandemic has shown that changes in society, economy and all other energy-usage areas of our societies are needed but also possible. At the same time, we have also seen the new rise of AI / Informatics, which is now considered the "new hope" as a technological enabler for numberless solutions, either easing the required transition, making our lives safer or more convenient. Energy Informatics is therefore needed more than ever, to create an environment for researchers and practitioners from different areas of energy systems as well as information technology to present new results and discuss innovative approaches and solutions. We are happy to present the proceedings of DACH+ Energy Informatics 2020, which is held in Sierre, Switzerland in October 2020.

Despite interruptions from the current pandemic, the DACH+ Energy Informatics series has continued to establish itself as the premier European conference in the field. This year, we received 42 submissions. The submissions came from 7 countries, which cover a wide range of topics such as smart grid, renewable energy, blockchain, electrical vehicle, etc. The Technical Programming Committee gave feedback on the submissions in the form of more than 120 reviews. For the third year of open-access proceedings in the Springer Journal of Energy Informatics, 15 full and short research contributions and 16 poster abstracts were accepted, resulting in an acceptance rate of $36 \%$.

This year's conference is organized and hosted by the University of Applied Sciences in Western Switzerland - HES-SO Valais-Wallis. Publication funding was provided by the Swiss Federal Office of Energy.

Sincerely,

René Schumann

General Chair (c) The Author(s). 2020 Open Access This article is licensed under a Creative Commons Attribution 4.0 International License, which permits use, sharing, adaptation, distribution and reproduction in any medium or format, as long as you give appropriate credit to the original author(s) and the source, provide a link to the Creative Commons licence, and indicate if changes were made. The images or other third party material in this article are included in the article's Creative Commons licence, unless indicated otherwise in a credit line to the material. If material is not included in the article's Creative Commons licence and your intended use is not permitted by statutory regulation or exceeds the permitted use, you will need to obtain permission directly from the copyright holder. To view a copy of this licence, visit http://creativecommons.org/licenses/by/4.0/. 
Roman Rudel

Technical Program Chair

\section{Khoa Nguyen}

Publication Chair

Acknowledgements

Not applicable.

\section{About this supplement}

This article has been published as part of Energy Informatics Volume 3 Supplement 1, 2020: Proceedings of the 9th DACH+ Conference on Energy Informatics. The full contents of the supplement are available online at https://energyinformatics. springeropen.com/articles/supplements/volume-3-supplement-1.

\section{Authors' contributions}

The authors read and approved the final manuscript.

\section{Funding}

Publication costs were covered by the DACH+ Energy Informatics Conference Organizers, supported by the Swiss Federal Office of Energy.

\section{Availability of data and materials}

Not applicable.

\section{Competing interests}

The authors declare that they have no competing interests.

\section{Author details}

${ }^{1}$ HES-SO Valais Wallis, SILab, Rue de Technpole 3, 3960 Sierre, Switzerland. ${ }^{2}$ SUPSI, Trevano - Blocco B, Via Trevano, 6952 Canobbio, Switzerland.

Published: 28 October 2020

\section{Publisher's Note}

Springer Nature remains neutral with regard to jurisdictional claims in published maps and institutional affiliations.

\section{Submit your manuscript to a SpringerOpen ${ }^{\circ}$} journal and benefit from:

- Convenient online submission

- Rigorous peer review

Open access: articles freely available online

High visibility within the field

- Retaining the copyright to your article

Submit your next manuscript at $\gg$ springeropen.com 